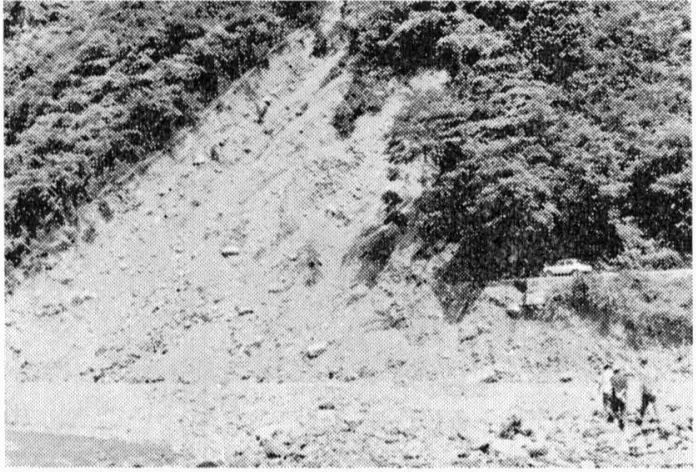

写真-6. 5 古い崩壊物の二次崩壊（世附川の浅瀬）

思わぬ急斜面に崖錐がのっている。

\section{3. 崩壊について}

(1) 山腹崩壊

地形拉よび林相のため崩壊個所数は明らかでないが, 極めて多数の山腹崩壊が発生している。これらは, 空中 写真の利用と判読によってかなり明らかにされるである ら。基岩からみると石英閃緑岩の崩壊・丹沢層群の崩壊・ 足柄層群の崩壊掞よび崖錐堆積物の崩壊にわけられる。

(a) 管杉の斜面崩壊は石英閃緑岩を扣扣っていたロー ム層が表層滑落型の崩壊を和こしたようである。く ずれ落らた上半部はガサガサのいわゆるマサ状であ り，下半部は崖錐堆積物の上を走り落らている。下 部の住家を全壊した（写真-6.1）。

(b) 山市場の崩壊は足柄層群の碩層がくずれたもので あり，崩土は $100 \mathrm{~m}$ 近く走り，これによって住家 の全壊と死者の災害をもたらした。

(c) 川ぞいの崩壊は丹沢層群・足柄層群および石英閃 緑岩で多数に発生しているのか，これらは足元を洪 水に洗われたことが大きな原因のようである。とき に, 洪水が川岸を大きく削り取っているものがある。 (d) 小渓流の崩壊は沢の側面や谷頭で多く発生してい

ホンコンのがけ崩れ桨害 概要

\section{まえがき}

47 年 7 月の梅雨前線による集中豪雨は, 全国にその猛 威を示し，各地に悲惨ながけ崩れ災害をひき牤こした。 一方，ホンコンでは， 6 月中旬の記録的な集中豪雨のた め九竜半島のカントン地区(Kwun Tong)のがけ崩れと ホンコン島ビクトリア地区 (Victoria) のビル倒壊を伴 ったがけ崩れの大きな災害があった。以下，上記の 2 地 区について，災害の概要を述べる。
る。これは鉄砲水発生の原因となり，渓流の土砂流 や土石流の誘因をなしている。間接的に大きな被害 をもたらした。

(2) 土石流

唐沢で大きな土石流が発生した。これによって，篣沢 部落では多くの住家が全壊した。沢の下流部では石英閃 緑岩の巨碩が累々として招り, 削り取られた両岸は石英 閃緑岩䃯と赤土とからなる厚い崖錐堆積物である。古い 時期の土石流が再び土石流として現われた様相を呈して いる。土石流の発生機構と対策は 1 つの研究課題である う。(写真-6.2)

(3) 土砂流

多数の渓流で発生している。上流部の側方崩壊や谷頭 崩壊が誘因となって発生している。かなりの䃏を押し出 しているが, 発生機構からみて土砂流とみなした。しか し, 土石流と土砂流とは明らかに区分しか゚たい点を含ん でいる。渓流の出口では崖錐堆積物を大きく削り取って いるものがある(写真-6.3)。

(4) 砂防堰堤

渓流の砂防堰堤・谷止め・床止めなどは, 渓流の崩壊 防止に大きな効果を有していた。砂防工事のため渓流崩 壊をまぬかれた例は多い。とくに，世附部落の寺の沢は 1 つの代表的な例といえよう。世附部落は寺の沢に接し た岩錐堆積物の上にあるが，寺の沢の崩壊をみなかった ため災害をまぬかれたようである。

\section{4. あとがき}

丹沢でみられた多害の概要をのべたが，多くの人によ って調査されているので，今後いろいろの問題点が明ら かにされてくるものと思われる。山腹や渓流において, 種々の形態の崩壊がみられたが, 発生機構の解明, 人的 ・物的災害の防止，治山・治水の対策など充分に検討さ れることが望まれる。

（通産省地質調査所・安藤 武）

\section{1. 災害概要}

ホンコンは気候帯は亜熱帯に属し，夏期に雨が多い。 年間降雨量は記録にある範井では, 1963 年の $901.1 \mathrm{~mm}$ が最低, 1889年の $3040.7 \mathrm{~mm}$ が最高の值であり, 平均* は $2168 \mathrm{~mm}$ である。今回，ホンュン政庁近くの観測所 の測定で，雨は 6 月16日降り始めて災害が発生した18日 までの 3 日間で，連続雨量 $640.1 \mathrm{~mm}$ あった。これは， 1889年の $762 \mathrm{~mm}$ に次ぐ観測史上 2 番目の記録で, 実に 82 年ぶりの雨が降ったことになる。図- 2 の等雨量線図 は 4 日間（15日午前 9 時〜 19 日午前 9 時）の総降雨量で カントン地区は $600 \sim 700 \mathrm{~mm}$, ビクトリア地区は 1000 $\mathrm{mm}$ 近く降っている。

\footnotetext{
* 日本の年平均降雨量は $1563 \mathrm{~mm}$ である。
} 


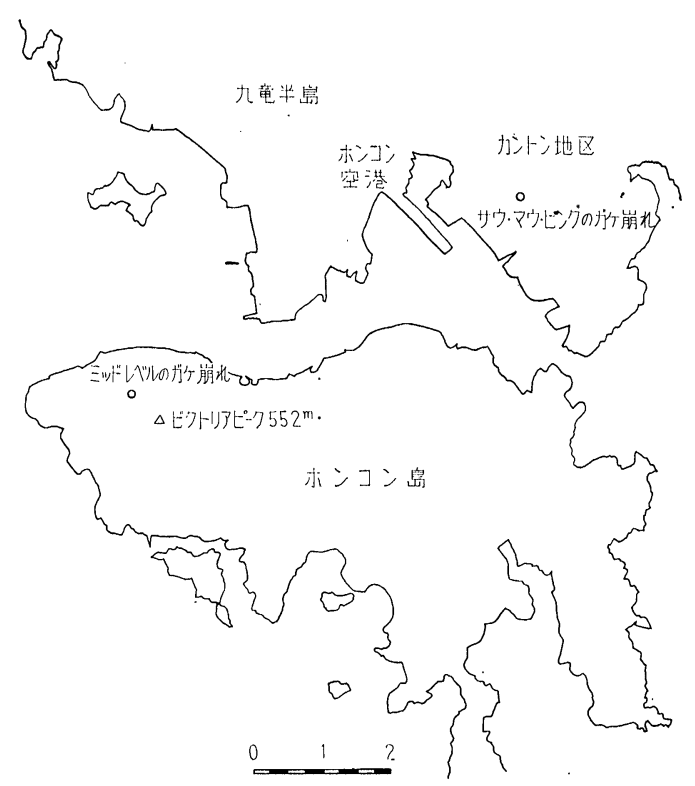

図-1 ホンュンの概略図

ホンコン大学のラム教授(Lumb) の論文によると, ホン コンの残積土は, 火成岩の化学的風化によって形成され ている。火成岩は，酸性火成岩の花崗岩と流䋌岩であり 夏期の高温多雨によって風化が促進され，拈よそ30m位 の媣さがある。浸透性等の違いから，風化度の大きい花 崗岩の方が，残積土層の厚さは厚いようである。図-3 より, カントン地区は, 花崗岩の風化帯であり, ビクト リア地区は，基岩が流紋岩の火山砕屑岩で覆われている 16，17両日もホンュン各地で小規模ながけ崩れや，河川
の汇濫，道路の決壊があった。そして最も規模の大きか ったのは，18日昼頃抗こったカントン地区のサウ・マウ ・ピング (Sau Mau Ping) のがけ崩れと, 夜 9 時頃特 こったビクトリア地区のミッドレベル (Midlevels) のビ ル倒壊を伴ったがけ崩れである。

(1) サウ・マウ・ピング（カントン地区）のがけ崩れ ホンコン空港の東側にあり, 基岩はジョイントの間隔 がひろい花崗岩より成っている。基岩の上層は，マサ状 に風化し，さらにその上に，小わゆる赤土化した表層が のっている。崩壊の様相は，写真- 1 で判るように山腹 に無許可に建てられていた貧民の小屋が約80軒土砂に流 され，70人近く死亡した。斜面に道路を作る際，山側の 切土した土砂を谷に埋め，末端に土留め擭壁を入れてい た。谷を埋める時に，谷の中央に排水パイプを暗渠にし て通し，道路山側の側溝の水を排水するようになってい た。崩壊の原因として考えられるのは，それまでの降雨 によってもともと谷部で地下水が集まり，間隙水圧が上 昇していたところに, 図一 4 より18日正午当時, 時間雨量 $100 \mathrm{~mm}$ 近くの豪雨がカントン地区に降り,さらに，急激 な水位上昇と表面侵食が重なって谷にあった捨土と，も との斜面の一部が崩壊したと考えられる。この時, 排水パ イプが地盤の滑りで, パイプに負荷がかかり切断したか, あるいは，排水パイプの通水能力を超えたかで，パイプ の水が外に出たことが崩壊発生の大きな原因であろう。

(2) ミッドレベル（ビクトリア地区）のがけ崩れ

ビクトリアピーク（標高 $552 \mathrm{~m}$ ) の中腹に崩壊が発生 した。基岩は，流紋岩であり，その上部はやはり風化さ

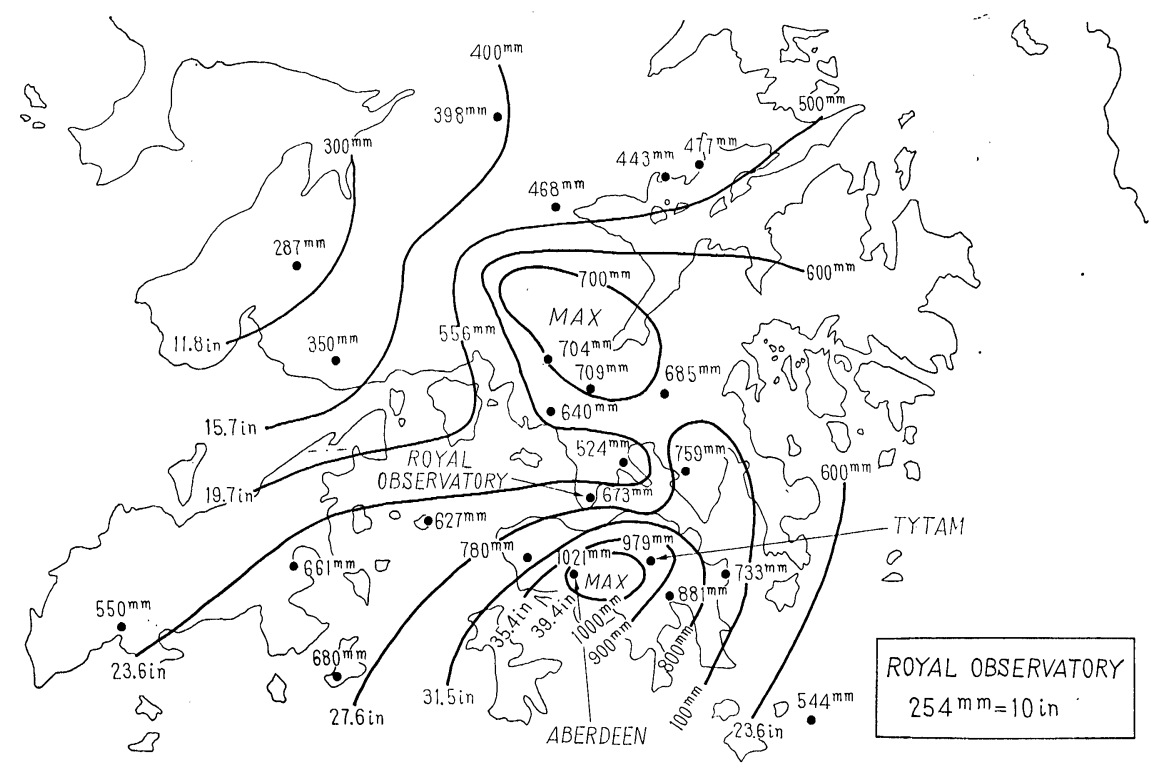

図-2 等雨量線図（6.15AM 9:00６.19 AM 9.00 4 日間） 

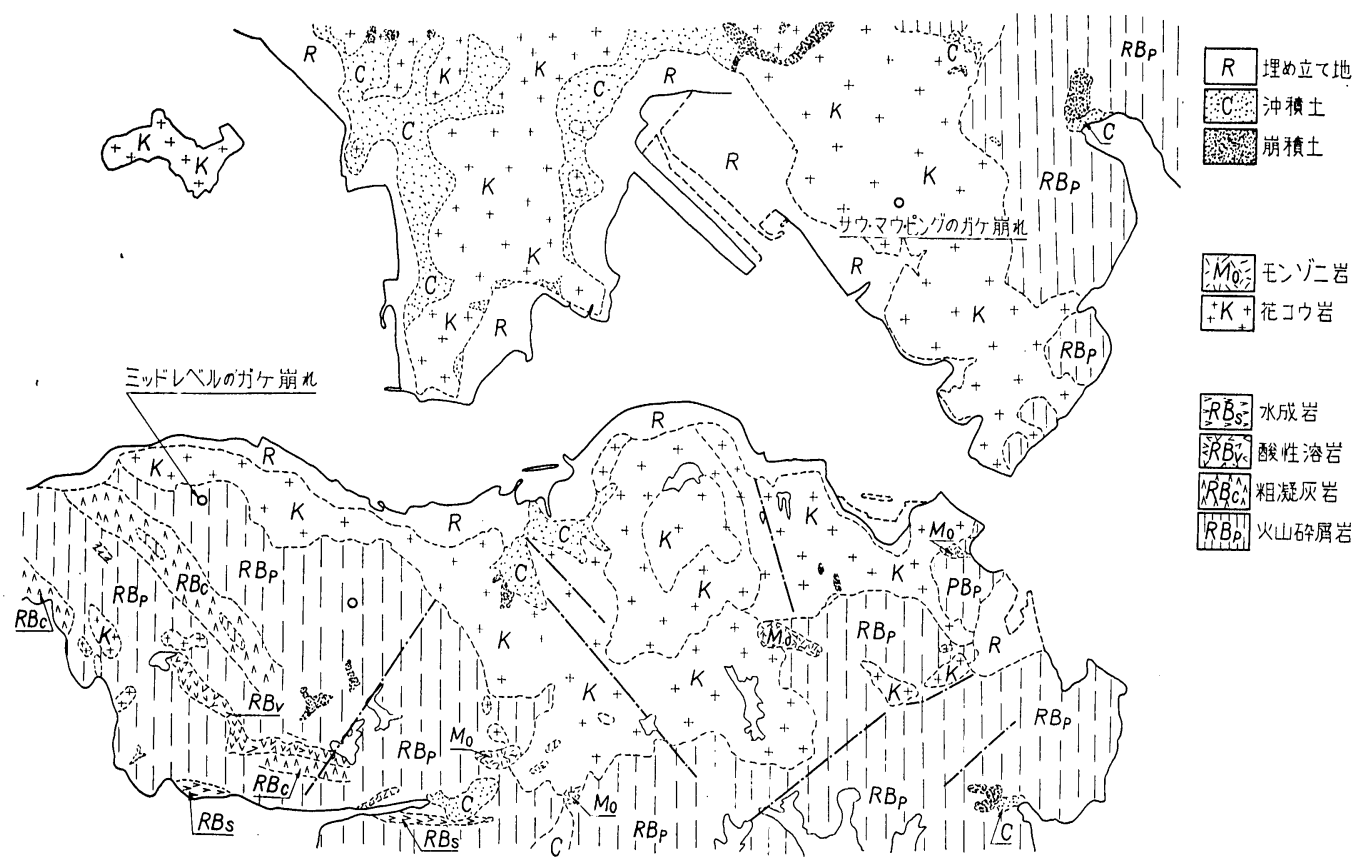

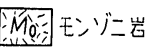

†K+ 花コウ岩

$R E_{s}^{*}$ 水成岩

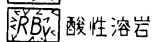

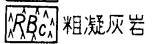

RBip. 火山碎罚岩

図-3 ホンュン地質図
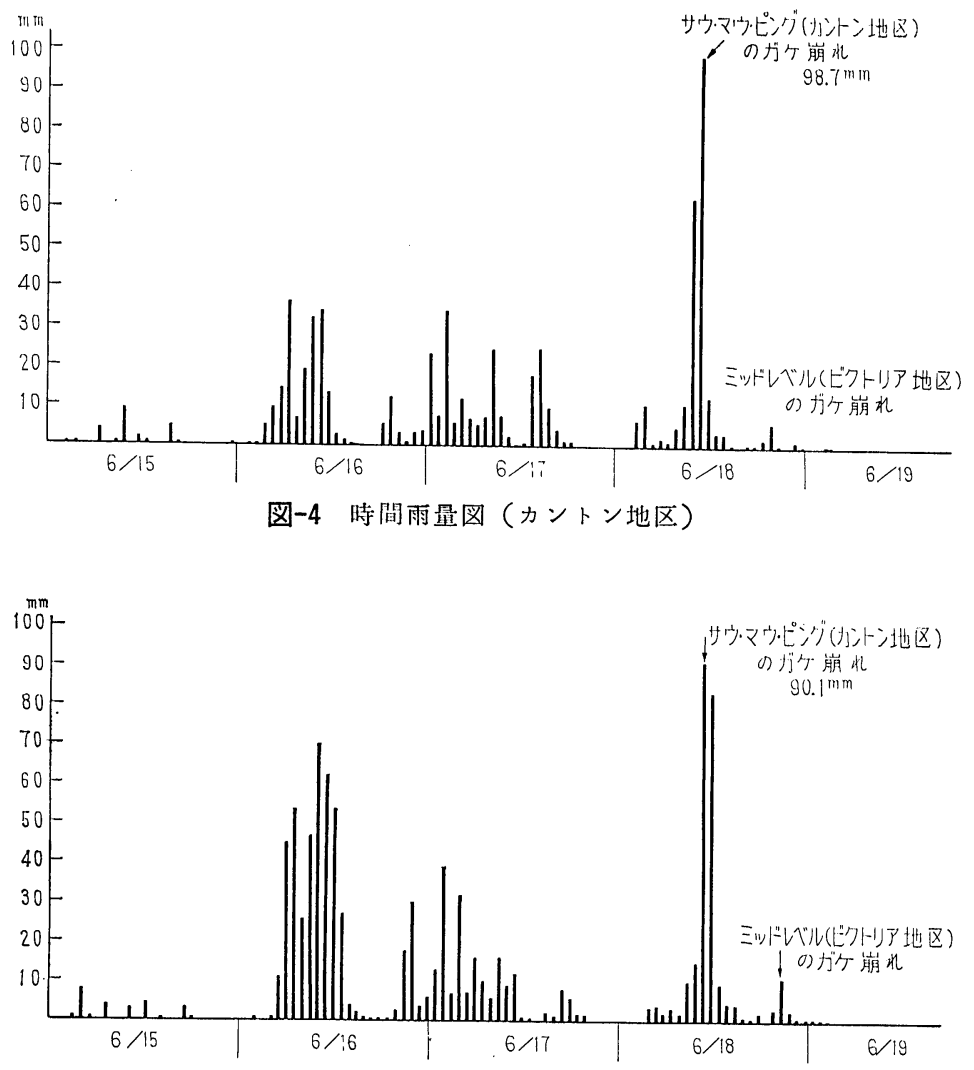

図-5 洔酒雨量図（ビクトリア地区） 
れている。困- 7 より災害の様子は, 山腹中部からの崩壊 が， 2 階建てのガレージを巻き込み，攡壁を破壊した。 その崩壊土砂が 4 階建てのビルの基礎に流れ込んでこの ビルを倒壊させた。この時, 下方にあった新築の 12 階建 てのマンションの上部 5 階までを削りとったのである。 崩壊頭部は中腹の傾斜 40 度近い急斜面上であり，傾斜が 緩から急に変換する付近で，地盤性状が上部と下部で異 なりこれが崩壊に結びついたとも考えられるがはっきり
しない。中腹の道路上の排水不良も一因と考光られる。 この災害はビルが倒壊する時, さらに下方のビルを削り 取り，側面の壁にはえぐれた跡が残っているという非常 に特異な災害だとい党る。急斜面下に建ち並ぶビルの風 景は，日本，とくに神戸などの街に多く見られ，今まで 経験がないとはいえ, 今後この種の災害が日本ではおこ らないという保障はどこにもない。これから, 急傾斜地 の建物に関して, 個々の安全性はもちろん, ホンョンの
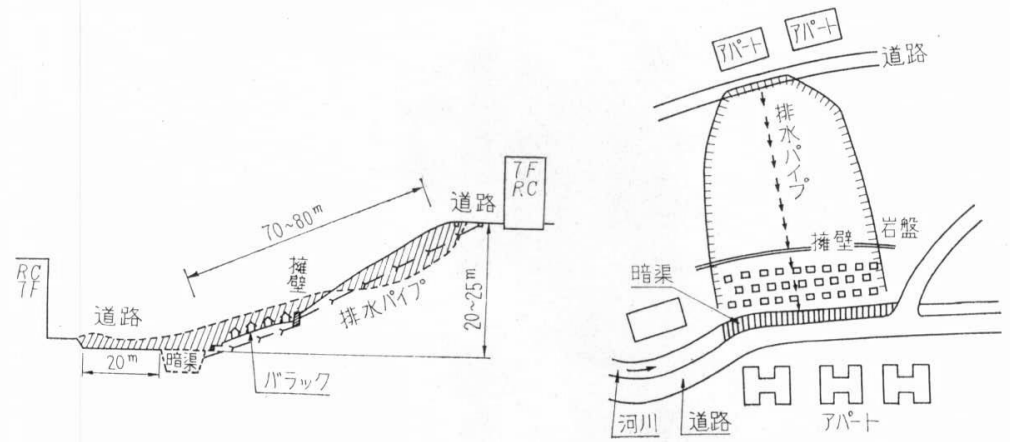

図-6 サウ・マウ・ピング（カントン地区）のガケ崩れ

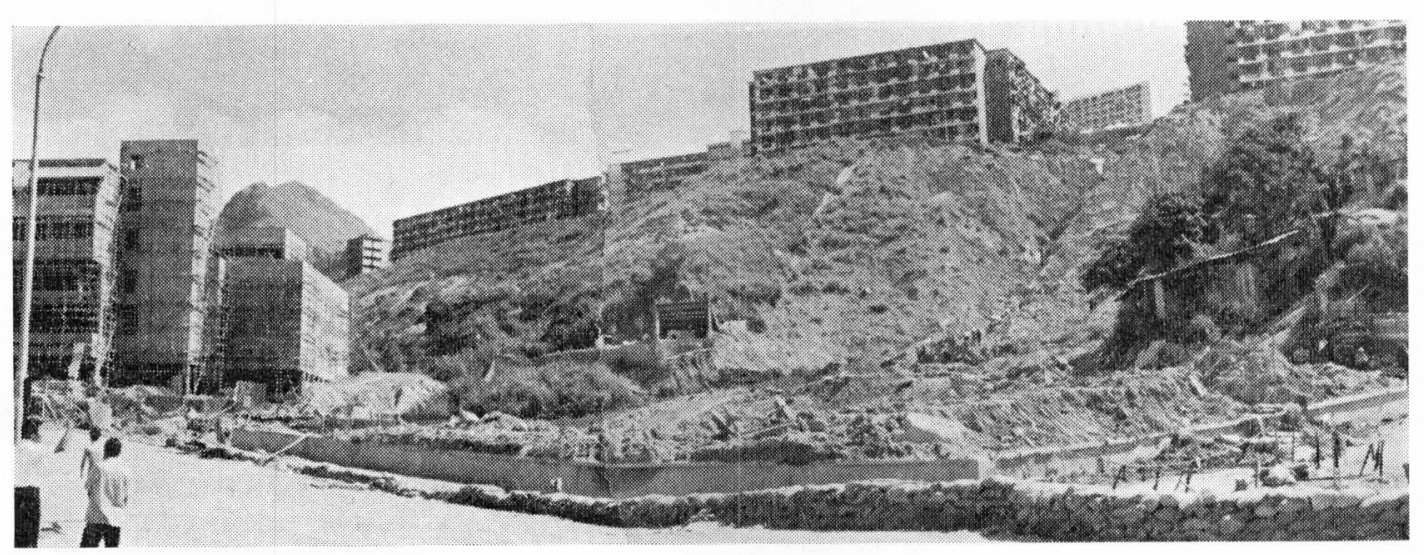

写真-1 サウ・マウ・ピング（カントン地区のガケ崩れ）
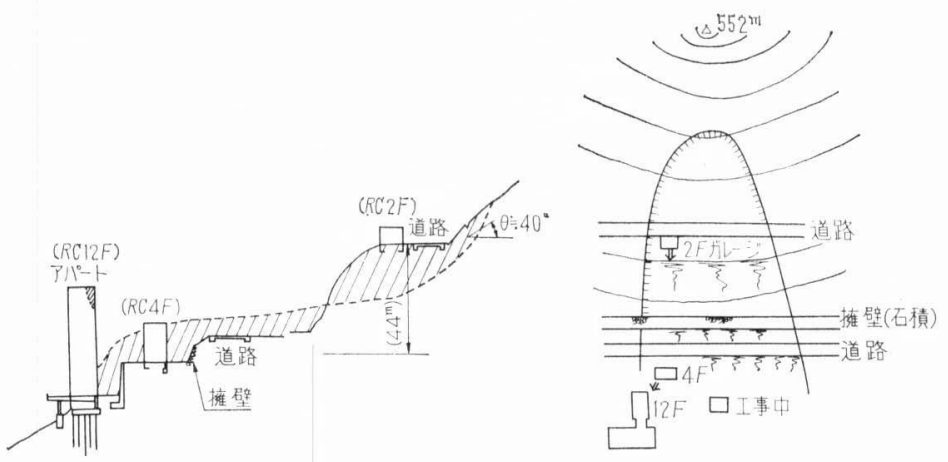

図-7ミッドレベル（ビクトリア地区）のガケ朋れ 


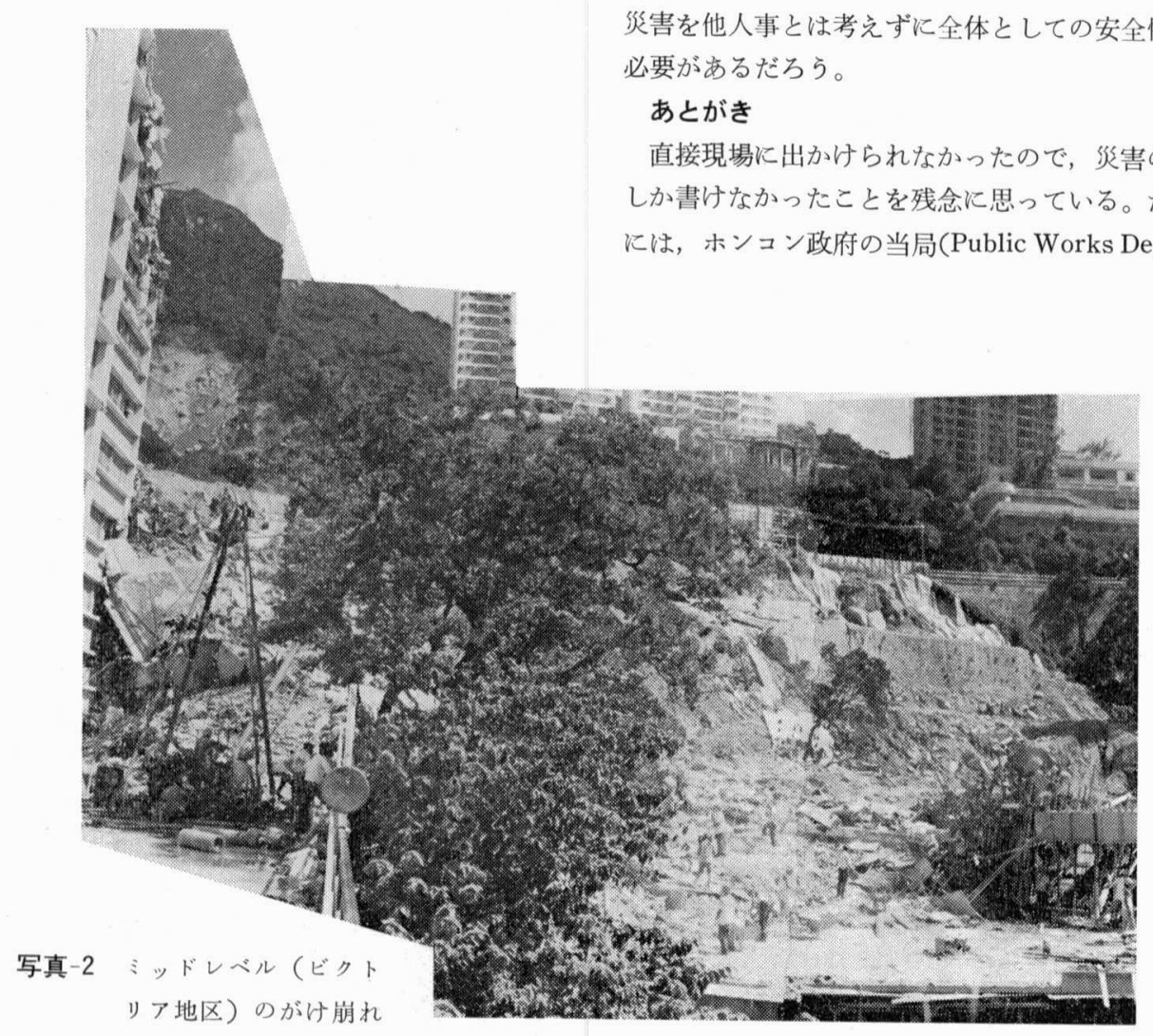

のロローク氏 (R’Orke) を代表とする 4 名の方が日本に 来られて，貴重な資料をいただいた事は有意義だった。 そして，今後も相互に情報を交換することにしている。
な抢本文中の地質図，等雨量線図，時間雨量図は口ロ一 ク氏の御好意により提供していただいたものである。 (土木研究所・急傾斜崩壊研究室 岡本正雄)
編集部よりの和知らせ

\section{一学会誌地す心゙り投稿規定改正の予告}

当学会も発足以来10年を算光, 先般記念行事が催 されましたが，これが一つの機会となって海外飞拉 ける地すべりの関係の機関, 研究者または技術者之 の間に交流を行なら要請が一段と強まりました。こ れに応党て編集部では学会誌に揭載する報文・論文 の内容を海外に紹介できるよう整備するため, 学会 誌の投稿規定を昭和 48 年度より改正することとしま したので予め御承知下さい。
改正点は，現行規定が報文・論文にはできる限り 英文要旨を添加するよう要望していたのに加えて,

“報文, 論文には和文要旨を添付すると共にできる 限り英交要旨を添付する。和交要旨は字数 300 字以 内で，和文要旨に用いた術語のみ和英対訳表を付 す。ただし英交要旨を添付した方は術語の和英対訳 表は不要です。”いらものです。

改正された投稿規定は 10 巻 1 号 (通巻 33 号) 揭 載し, この号から適用しますが, 向後 (9巻 3 号) 御投稿下さる場合は和交要旨と英文要旨（できるだ け）を添付して下さい。 